\title{
A conspiração dos vivos: as lutas contra a asfixia
}

\section{The conspiracy of the living: the struggles against asphyxiation}

\section{Murilo Duarte Costa Corrêa*}

Resumo: Este ensaio analisa o panorama e o desenvolvimento das lutas sociais durante a pandemia da Sars-Cov-2, com atenção aos seus desdobramentos entre março e julho de 2020. Recorrendo a uma metodologia teórico-empírica, e combinando a análise teórica à de conjuntura, o ensaio examina quatorze textos de intervenção escritos pelo filósofo italiano Giorgio Agamben no contexto pandêmico. Esses textos manifestam grandes preocupações com o futuro da atividade política, em função da adoção de políticas de lockdown e de distanciamento social. Tornada um problema de pesquisa, analisamos criticamente e ressignificamos essa preocupação de um ponto de vista materialista e pós-estrutural, recorrendo às obras de Deleuze e Guattari, Pasquinelli, Quintarelli, Tiqqun e Judith Butler, entre outros pensadores contemporâneos. Analisando conjunturalmente os movimentos Black Lives Matter, Stay at Home e o Breque dos Apps, o ensaio conclui que o campo social pandêmico constitui um solo fértil ao florescimento de novas lutas, estratégias, e relações de composição política entres os corpos, ainda que secundado de perigos.

Palavras-chave: Pandemia. Coronavírus. Movimentos sociais.

\begin{abstract}
This essay analyzes the panorama and the development of social struggles during the Sars-Cov-2 pandemic, with attention to its developments between March and July 2020. Using a theoretical and empirical methodology, and combining those with conjuncture analysis, the essay examines fourteen intervention texts written by the Italian philosopher Giorgio Agamben in the pandemic context. These texts manifest great concerns about the future of political activity, due to the adoption of lock-down and social distance policies. Gathering it as our research problem, we have critically analyzed and re-framed this concern from a materialistic and post-structural point of view, resorting to the works of Deleuze and Guattari, Pasquinelli, Quintarelli, Tiqqun and Butler, among other contemporary thinkers. Having analyzed the movements Black Lives Matter, Stay at Home and "Breque dos Apps"
\end{abstract}

* Doutor (USP) e Mestre (UFSC) em Filosofia e Teoria Geral do Direito e Graduado em Direito (UFPR). Professor Adjunto no Departamento de Direito do Estado e do Programa de Pós-Graduação em Ciências Sociais Aplicadas da UEPG. E-mail: correa@uepg.br. 
conjuncture, the essay concludes that the pandemic social field constitutes a fertile ground for the flourishing of new struggles, strategies, and relations of political composition between the bodies, although supported by dangers.

Keywords: Pandemic. Coronavirus. Social struggles.

Recebido em 28/07/2020. Aceito em 24/09/2021

\author{
"Quanto ao futuro, escute: \\ seus filhos fascistas \\ velejarão \\ rumo aos mundos da Nova Pré-História. \\ E eu estarei lá, \\ como aquele que sonha sua desgraça \\ sobre as orlas do mar \\ em que a vida recomeça". \\ Pier Paolo Pasolini, \\ Uma vitalidade desesperada
}

\title{
Introdução
}

O presente ensaio analisa sob uma perspectiva interdisciplinar o panorama e o desenvolvimento das lutas sociais no transcurso da pandemia da Sars-Cov-2 (o vírus Covid-19), com especial atenção aos seus desdobramentos entre março e julho de 2020. Para tanto, revisa criticamente uma série de quatorze textos de intervenção escritos pelo filósofo italiano Giorgio Agamben no contexto pandêmico ao lado de três movimentos que emergiram no contexto pandêmico: o black lives matter, o stay at home e o Breque dos Apps.

Publicados entre 26 de fevereiro e 13 de julho de 2020, os textos de Agamben sobre a pandemia desencadearam uma viva polêmica nos meios intelectuais e no espaço público de debate sobre a pandemia. O primeiro deles, L'invenzione di un'epidemia (26 de fevereiro de 2020), argumenta que a epidemia -- que 14 dias mais tarde viria a ser declarada uma pandemia pela Organização Mundial de Saúde -- não passaria de uma invenção dos poderes constituídos para ampliar a eficácia das medidas de exceção em curso. A afirmação de Agamben despertou uma série de reações mundo afora, bem como na cena intelectual brasileira.

No contexto dessa polêmica, os textos de Agamben desenvolvem uma série de teses correlacionadas com sua obra política anterior. Neste ensaio, ocupamo-nos, em um primeiro momento, em analisar detida e imparcialmente as condições hermenêuticas e ético-políticas que sustentam os textos de Agamben. Reservamo-nos o direito de não ingressar no mérito polêmico, por parecer-nos pouco frutífero. Em chave alternativa, extraímos das múltiplas teses que Agamben desenvolve sobre a pandemia uma preocupação recorrente, e que nos parece especialmente 
problemática: aquela em que Agamben denota inquietação com o destino das lutas sociais na era do distanciamento social. Fazemos dessa inquietação o problema e o fio condutor ao redor do qual este ensaio se desenvolve.

A fim de evitar qualquer injustiça, remontamos nos itens n. 1, 2 e 3 as condições gerais que justificam tal preocupação. Isso exigiu que realizássemos uma releitura e uma reconstrução metódica e crítica dos principais pontos dos argumentos de Agamben, distribuídos ao longo dos quatorze textos de intervenção reunidos no site Quodlibet.

Em seguida, essa preocupação é analisada criticamente e ressignificada a partir de um ponto de vista materialista e pós-estrutural, baseando-se em três premissas que são exploradas no item 4. Elas consistem em uma breve redefinição do campo social, compreendido já não mais a partir de suas contradições, ou de uma estrutura, mas do que Deleuze e Guattari chamaram de suas "linhas de fuga"; na afirmação da realidade dos processos imateriais ou virtuais, a partir de uma pluralidade heterogênea de críticos contemporâneos do capitalismo -- referimo-nos, especificamente, a Pasquinelli, Quintarelli e ao coletivo Tiqqun; e, por fim, completamos a segunda premissa valendo-nos da crítica que Judith Butler endereçou ao ideal de uma esfera política separada da esfera da vida reprodutiva -- divisão que, em sua crítica, destina-se a divergir da Hannah Arendt de A condição humana, mas remonta à política de Aristóteles e reverbera na divisão entre vida nua e vida política de Giorgio Agamben. Nesse ponto, são mobilizados topicamente outros autores, em diálogo com Butler, como Achille Mbembe, Éric Alliez e Maurizio Lazzarato

Estabelecidas essas três premissas teóricas, que tornam possível redirecionar a preocupação original e conjuntural de Agamben com "o futuro do político" na era do distanciamento social, o item n. 5 analisa diretamente a conjuntura o caso de três lutas biopolíticas na situação pandêmica, a partir de três terrenos ambíguos, povoados por perigos e chances.

Em primeiro lugar, a reemergência global do Black Lives Matter em torno do homicídio policial cometido contra George Floyd em Minneapolis: lutas globais que se beneficiaram de transversalidades e alianças com movimentos autonomistas, antirracistas e antifascistas.

Em segundo lugar, o espaço doméstico, situado em uma série de conexões inesperadas entre o devir-doméstico do trabalho produtivo (home office), a nova visibilidade do labor reprodutivo (tradicionalmente feminino), a questão global da renda biopolítica e uma ecopolítica das casas, organizada não apenas por uma tendência global de lockdown, mas pela autonomia dos vivos sob a forma do movimento \#stayathome. Aqui, as afinidades eletivas estão dadas pela nova visibilidade do trabalho reprodutivo e feminino, destacada por Silvia Federici, as casas como novos espaços ecopolíticos globais e uma convergência do labor reprodutivo não-comercializado e o problema da renda biopolítica.

Por fim, na fusão muito material entre o real e o virtual exploramos o \#BrequedosApps, um movimento contestatório catalisado pelos entregadores antifascistas no Brasil e operado na conexão entre ruas, redes, exploradores e algorítmicos, capitalismo de plataforma, precariado e co-produção dos consumidores.

Essa análise é, por um lado, conjuntural, mas também procura estabelecer, seguindo as articulações das forças sociais e econômicas em relação na pandemia, algumas das direções em que se reparte um monismo das lutas no terreno pandêmico. A isso chamamos conspiração dos vivos, que, ao confrontarem o risco da asfixia, convertem-na em um terreno de lutas em que estão em jogo as suas "vidas de seres vivos".

Ao mesmo tempo em que, no plano conjuntural, a análise aponta uma série de limiares de positividade das lutas em curso -- tornando a questão de Agamben sobre "o futuro do político" 
imediatamente obsoleta --, ela também descerra uma série de atualidades perigosas, como os anti-mask protests americanos, o governo diferencial das precariedades e vulnerabilidades, as gestões necropolíticas governamentais etc. Isso reforça que se, por um lado, uma sociedade é o conjunto de suas linhas de fuga, sabemos que as linhas de fuga também encerram perigos, e podem proliferar como linhas de abolição e microfascismos, consolidando formas de vida assassinas ou suicidas.

É assim que o que para Agamben soava como um problema -- o distanciamento social --, aparece agora não como uma condição adversa à atividade política, nem como uma política de Estado, mas como uma ética e uma tática desdobrada no monismo das lutas contra a asfixia. Uma condição e uma prática estratégica que atravessa diferencialmente todos os espaços (casas, ruas, redes etc.) e dinâmicas políticas (presenciais e não-presenciais, sincrônicas e diacrônicas) como um ethos encarnado na forma e na vida das lutas que estão em curso.

\section{Faticidade e liberdade}

Em um conjunto de textos recentes, Giorgio Agamben (2020a) manifestou sérias preocupações com a adoção frenética de medidas de exceção pelas autoridades italianas. Sugerindo uma escalada sem precedentes da vigilância tecnopolítica e da biossegurança (AGAMBEN, 2020b), colocou em xeque o destino das lutas sob a injunção sanitária do distanciamento social. O efeito das políticas de distanciamento social não teria sido o alvorecer de um novo tipo de hiperindividualismo, mas a composição de uma massa por inibição (CANETTI, 2019): negativa, rarefeita, compacta e passiva, desprovida da capacidade de realizar movimentos livres, e à espera de um chefe (AGAMBEN, 2020c).

Ao refletir sobre a situação pandêmica, Agamben não assume um compromisso efetivo com outra realidade, exceto com aquela derivada dos poderes teológico-políticos. Nela, a medicina se transfigura em uma religião secularizada da biossegurança, e o biopoder se cruza escatologicamente -- não sem atritos -- com o cristianismo e o capitalismo (AGAMBEN, 2020d). Eis o que lhe permite denunciar que temos nos deixado governar pelo medo irracional e factício do vírus, hiperbolicamente chamado de "o menor de todos os entes intramundanos" (AGAMBEN, 2020g).

Esse conjunto de preocupações foi alvo de numerosas críticas -- muitas delas justas; outras, a nosso ver, nem de longe sóbrias ${ }^{1}$. Dois fatores parecem tê-las desencadeado. Por um lado, Agamben assume uma perspectiva ético-política voluntariamente desligada da vida em sua suposta nudez, e do vírus, em sua pura faticidade. Esse gesto filosófico revela-se já em Una domanda, texto em que Agamben (2020e) pergunta: "Como foi possível que um país inteiro [a Itália] tenha entrado em colapso ético e político diante de uma doença?”. Ainda, e com maior clareza, em Che cos’è la paura? (2020g), ele questiona "O que é o medo, no qual, hoje, os homens parecem de tal modo caídos, a ponto de esquecerem as próprias convicções éticas, políticas e religiosas?”.

Por outro lado, essa denúncia se apoia em uma hermenêutica da faticidade de inspiração heideggeriana. E, aqui, Agamben parece levar a sério a prescrição heideggeriana de que "O que interessa é uma explicação hermenêutica, não uma informação mundana do que se passa", de modo que "é necessário transpor o domínio fenomenal da faticidade. Pois somente então será possível colocar a questão óbvia se [...] acertou-se o ‘hoje’ ou não” (HEIDEGGER, 2012, p. 38-39).

\footnotetext{
${ }^{1}$ Entre os textos que se ocuparam dessa polêmica, direta ou indiretamente, poderíamos registrar o texto de Grillo (2020), de Nancy (2020), de Esposito (2020) e de Diwedi e Mohan (2020). No Brasil, os textos de Corrêa e Matos (2020), de Yara Frateschi (2020 a; b), de Carla Rodrigues et al. (2020), de Juliana de Moraes (2020) e de Barbosa e Honesko (2020).
} 
Assim, seus textos só podem ser adequadamente interpretados e criticados na medida em que se compreenda que o plano ético-político de questionamento, mais explícito nos primeiros textos, depende de um movimento que só se esclarece plenamente a posteriori, nos últimos escritos, e que coincide com uma transfiguração hermenêutica e existencial da faticidade e da falação do Dasein, impessoal e desprovida de nuance.

É no cruzamento entre o plano ético-político e seu solo existencial, tomado como ponto de partida discreto, que Agamben procura ultrapassar o que Heidegger chamou de "ser-aí fático, um como da fatalidade específica da faticidade, fatalidade à qual toda vida fática paga seu tributo", para dar ao "ser-aí fático o caráter de um estar orientado", e delimitar "muito bem seu possível modo de ver e o alcance de sua visão" (HEIDEGGER, 2012, p. 40). Estamos às voltas com a relação entre os existenciais e a cotidianidade; isto é, com o problema do sentido da faticidade mesma, cujo "em-si" decai, supérfluo, ante o "para-si", que encerra todo o risco da liberdade.

\section{O dispositivo polêmico}

É no texto de 13 de julho de 2020 que Agamben parece dizer efetivamente tudo sobre suas premissas para analisar a pandemia. O medo é tratado a partir da ontologia de uma tonalidade emocional que constitui a "abertura originária ao mundo" do Dasein heideggeriano. Sem se confundir com um estado psicológico, o medo aparece como "[...] um modo fundamental da disposição emotiva que abre o ser humano em seu ser sempre e já exposto e ameaçado" (AGAMBEN, 2020g; cf., ainda, HEIDEGGER, 2009, p. 199-202).

Por um lado, o medo se refere a um ente intramundano, sem relação com a abertura, e que não transcende a pura faticidade. Por outro, ele é, para o Dasein, "a tonalidade emotiva que se descerra quando o homem, ao perder a conexão entre o mundo e as coisas, encontra-se irremissivelmente entregue aos entes intramundanos e não pode chegar ao fundo de sua relação com uma 'coisa', que ora se torna ameaçadora" (AGAMBEN, 2020g). A coisa que aterroriza é, então, "a encarnação [de uma] incontornável coisalidade” (AGAMBEN, 2020g) que culmina em impotência, paralisia e irracionalidade.

É nesses termos que Agamben distribui dois planos de análise: um, povoado pela pura faticidade viral e determinado pela tonalidade emotiva "esquecida" da abertura e do próprio ser-no-mundo, dada por uma "coisalidade abstratamente separada e erigida indevidamente como soberano"; outro, hermenêutico, que tenta envolver o primeiro ao divorciar-se dele. Neste plano, a memória da abertura originária restitui a possibilidade de ditar "as regras éticas e políticas do meu comportamento" (AGAMBEN, 2020g), na medida em que a coisalidade é rememorada no aberto e revelada unicamente pelo ser-no-mundo. Essa memória, que não se confunde com uma racionalização, rompe a relação entre a coisa (o vírus, a nudez da vida) e a tonalidade emotiva do medo que, descerrando o homem para a abertura, também arrisca bloqueá-la.

Tudo, então, se funda no esquecimento do ser, da abertura, da copertença do vírus e da vida nua ao mundo que os transcende. Agamben faz a corajosa defesa de uma memória a fim de combater o medo e a sua tristeza impotente, que se tornaram as condições ideais para o desenvolvimento de novos poderes a nos sujeitar -- e isso é tão apropriado quanto belo. Mas também reduz o vírus à inerme faticidade de uma ameaça abstrata que só adquire sentido quando se transforma em uma "possibilidade repentinamente real" a inspirar "cautelas oportunas" -- o que talvez seja transigir existencialmente demais com o real. 
Tudo se passa como se recordar a abertura franqueasse imediatamente um plano de negociação ético-político imunizado, em que a vida parasitária do vírus e a da vida nua se equivaleriam, porque decaídos no horizonte da pura faticidade, cujo valor de real depende de um plano hermenêutico doador de sentido. A hermenêutica que deveria envolver a faticidade em seu sentido gera, paradoxalmente, uma desagregação entre os planos do ser efetivo e do agir. Isso faz com que Agamben tenha de confiná-los à abertura como via de saída da própria faticidade, uma vez que ela constitui um dos polos dados pela máquina ontológico-política do Ocidente. Agamben pensa a pandemia na abertura e, portanto, na suspensão da dicotomia entre o ser e o ente (AGAMBEN, 2002, p. 93-94).

Essa hipótese de leitura é confirmada por Sulla fine del mondo (AGAMBEN, 2019). Nesse texto pré-pandemia, de 18 de novembro de 2019, Agamben já havia predisposto o centro de um dos argumentos que reencontraríamos em La Medicina come religione (AGAMBEN, 2020d) e em Biossicurezza e politica (AGAMBEN, 2020b). Trata-se da afirmação de que, na modernidade, a ciência se entrelaça com a fé para se tornar uma religião, gerando um cruzamento escatológico, por vezes adversarial, entre ciência e capitalismo. Essa escatologia, inédita para a ciência, se assumiria na tarefa de profetizar e fazer crer no fim do mundo derivado da catástrofe ambiental, segundo a crítica que Agamben endereça à ativista sueca Greta Thunberg. Sinal de que, no caso da catástrofe ecológica, como no da crise sanitária, Agamben dirige sua crítica mais aos efeitos ético-políticos nascidos de uma hipótese teológico-política com que cofina o real do que analisa a "nudez" do seu núcleo vivo.

As últimas linhas de Sulla fine del mondo deixam claro que não se trata de se pronunciar sobre "a realidade do problema da poluição", mas de não se deixar governar acriticamente pelas religiões da ciência ou do capital na análise de "escolhas e razões que não podem ser senão políticas" (AGAMBEN, 2020b). Isso sugere uma análise que, a exemplo do dispositivo teológico medieval, parece demandar que o agir (a práxis, a política) se faça sem qualquer fundamento no ser (AGAMBEN, 2009, p. 38; AGAMBEN, 2011, p. 67-81). Ou, talvez pior, que o ser prossiga paradoxalmente engastado à máquina ontológico-política em sua escalada metafísica.

\section{Filosofia do contato}

Essas hipóteses polêmicas propõem uma questão muito materialista às lutas e aos antagonismos no terreno social. Em Fase 2, Agamben (2020f) diagnosticava o retorno à normalidade como um cenário de controle ilimitado e distanciamento social, porque, na gestão do lockdown e de sua progressiva flexibilização, o Estado italiano propunha uma série de medidas violadoras de direitos civis e políticos.

As principais restrições incidiam sobre o direito de ir e vir dos mais idosos. Criando cidadãos de segunda classe, impunham testagem em massa da população, bem como medidas de distanciamento social que inviabilizariam reuniões, tornando impossível, nas palavras de Agamben (2020f), "toda atividade política real". Biosicurezza e politica exprime, ainda, a preocupação com o desmoronamento da proximidade, "a perda das relações sensíveis, do rosto, da amizade e do amor", e questiona se elas podem ser compensadas "por uma segurança de saúde abstrata e presumivelmente fictícia [...]" (AGAMBEN, 2020b).

Esse temor parece fazer eco à filosofia do contato que Agamben (2017, p. 266) tira a Giorgio Colli no volume de encerramento do projeto Homo Sacer. Sua forma-di-vita parece encontrar, aí, 
em retrospecto, todo o seu sentido: "uma intimidade não mediada por alguma articulação ou por alguma representação” (AGAMBEN, 2017, p. 266). O contato, como um nada de representação entre-dois, resume toda a política de Agamben: baseada na destituição das relações (representações operadas pela exceção teológico-política que anima o jurídico e suas formas de captura exterior) em proveito de um contato (thigein) que é, já, um nada de representação entre forma (bíos) e vida (zoé), que permanece irrepresentável e, nessa qualidade, constitui o "centro oculto" incapturável da máquina ontológico-política do Ocidente, servindo-lhe de shabbat -- ou de sabot.

Por isso, Agamben (2011, p. 265) pode dizer que "A forma-de-vida é esse bando, que não tem mais a forma de um vínculo [i.e., de uma relação], de uma exclusão-inclusão da vida nua, mas aquela de uma intimidade sem relação [i.e., de um contato]". o contato é, pois, o irrelato e o irrepresentável que definem uma vitalidade propriamente política como a forma não-representativa em que uma vida toca sua forma, e uma forma toca uma vida, passando a habitar uma não-relação.

O que, no entanto, Agamben parece situar à parte - especialmente ao analisar a situação pandêmica - é que o contato não é especialmente metafísico, nem descreve condições exclusivamente transcendentais. Se seu interesse pelo conceito de contato de Giorgio Colli é tão vivo, é porque ele exprime uma "regressão arqueológica" (AGAMBEN, 2017, p. 268) que contém "não uma unidade cronologicamente mais originária, ou uma unidade nova e superior", mas "uma saída" (AGAMBEN, 2017, p. 268) .

Essa saída consiste em um êthos ( $\tilde{\eta} \theta o \varsigma)$ que designa o uso pelo qual uma vida e sua forma habitam politicamente uma não-relação na qual as formas de vida se comunicam em um regime de intimidade e coabitação, e testemunham o co-pertencimento (o contato) dos opostos: vida e forma; física e metafísica; ontologia e política. Exatamente como a abertura testemunha o "co-pertencimento das coisas ao mundo que as transcende e as faz presentes" (AGAMBEN, 2020g), a co-pertença do contato é o que dissolve tanto as divisões dos opostos quanto as articulações paradoxais que os sujeitam à forma de uma relação de exclusão-inclusiva, de exceção ou de bando ${ }^{4}$ -- que é, no fundo, o conteúdo formal de toda relação.

\footnotetext{
${ }^{2}$ É interessante notar como Homo sacer é, para Agamben, um projeto aberto. Seu primeiro volume, de 1995, desconhece sua posteridade (2014), que aguardará quase vinte anos por um desfecho cuja definitividade seus leitores, comentadores e críticos ainda estão em vias de estabelecer. Assim, parece-nos que é nos últimos textos de Agamben que poderíamos encontrar os princípios capazes de atribuir sentido ao projeto como um todo. Se em Homo sacer I Agamben pretendia que a pesquisa concernisse ao "oculto ponto de intersecção entre o modelo jurídico-institucional e o modelo biopolítico de poder" (AGAMBEN, 2007, p. 14), é somente vinte anos mais tarde que Agamben torna esse centro claro e, a nosso ver, o faz a partir de um comentário de Giorgio Colli dedicado a Aristóteles (COLLI, 1982, p. 348-349). Entre os dois momentos, vemos proliferar uma sucessão de conclusões provisórias cuja pertinência só a partir de 2014 pode ser avaliada em toda a sua extensão, e ainda deve colocar aos seus intérpretes uma série de problemas difíceis de superar.

${ }^{3} \mathrm{O}$ mesmo tipo de saída que Agamben parece buscar à coisalidade sem mundo, à faticidade inexorável do vírus ou à nudez da vida. Uma saída da relação que bloqueia o irrelato, e da representação que confina o irrepresentável. Esta saída é o contato. Rememorar a abertura, a condição de possibilidade da própria atribuição de uma esfera de coisalidade ao Dasein, é manter-se em contato com o irrelato e o irrepresentável que torna possíveis todas as relações e representações, sem participar de nenhuma delas. Uma saída tanto da ontologia quanto da práxis, que permite suspender o sentido de ambas, bem como, em um mesmo gesto, o êxodo do fatalismo de sua articulação paradoxal.
}

${ }^{4}$ Para seguir essa intuição, arriscaria dizer que Agamben se interessa tanto pela exceção, como o paradigma que separa e mantém unidos vida, direito e violência, porque descobre nela uma relação aparentemente incindível. Todavia, descrevêlo como um crítico do estado de exceção seria ocultar o coração de sua filosofia, que parece melhor qualificada como uma filosofia da ruptura relacional, que se multiplica destituindo relações por onde passa: vida, violência e direito, homem e animal, vida e forma, soberania e homo sacer, ser e agir, ontologia e política, nomos e anomia, linguagem e ser, representação e irrepresentável, relação e irrelato etc. Toda filosofia de Agamben, a nosso ver, poderia ser resumida à tentativa original 
Ao invés de representar a física e a metafísica, encontramos em uma filosofia do contato "o irrepresentável", o limiar de indiscernibilidade que transforma "metafísica" e "corporalidade" em categorias abstratas demais para representar o que já não pode ser representado. O defeito não se encontra nesse "terceiro gênero de conhecimento", que não está contido nem na metafísica nem na física; o defeito consiste na própria representação como uma díade de opostos ligados por uma relação de exceção que os exclui reciprocamente apenas para mantê-los unidos.

O contato é o conceito que reverte a operação perniciosa que fratura (mysterium disjuncitionis) a ontologia e a política (AGAMBEN, 2002, p. 21-24) apenas para relacioná-las sob o modo de uma exclusão-inclusiva. Para muito além do ser e do agir, uma filosofia do contato é o próprio "centro da máquina ontológico-política" que os desativa; "um limiar de indiscernibilidade em que a dicotomia falta e os opostos [...] caem juntos" (AGAMBEN, 2017, p. 268). Eis a saída que a filosofia política de Agamben aguarda pelo menos desde 1995, e que rejeita a faticidade e a ontologia do Ocidente como abstrações operatórias do poder.

Segundo Colli (1982, p. 349), o contato é o inverso de uma representação, ou da relação que ela pressupõe: é “a indicação de um nada representativo", uma não-relação que aglutina dois pontos, ao mesmo tempo em que lhes "proporciona uma colocação-espaço temporal", uma determinação, um "habitar", um dos sentidos etimológicos de "êthos" ( $\tilde{\eta} \theta 0 \varsigma)$.

Por isso, Colli (1982, p. 348) diz que nunca se trata do "ponto de contato", que não existe; que é uma abstração que permanece, como quantidade matemática qualquer, infinitamente divisível. o contato é, ao contrário, "um certo nada", um "nada determinado" (COLLI, 1982, p. 349). Enquanto a relação e a representação indicam o ilimitado, o infinito, o próprio Deus de que o soberano é a imagem homóloga secularizada, o contato condiz com o limitado, o finito e, portanto, com a forma-di-vita que designa o irrelato, o irrepresentável e o vivo absolutamente inseparável de seu ser e sua forma.

\section{Distanciamento e política}

O problema é que Colli, e sua filosofia do contato, são rebatidos em Heidegger, e em sua hermenêutica ainda demasiado metafísica. É precisamente o contato situado, sua finitude e limitação, que coincide com a dimensão irrepresentável do vivo (forma-di-vita), que Agamben tenta salvar aos poderes em curso. Ao mesmo tempo, paradoxalmente, Agamben o abstrai nos textos sobre a pandemia, deixando-se absorver nas denúncias sobre a escalada ilimitada e hiperbólica dos controles tecnopolíticos.

As questões que Agamben formula no contexto da pandemia não deixam de ser dignas de preocupação. Porém, sob o pretexto de fazer ver o quanto estamos enredados na hipervigilância, na biossegurança e em uma crise de proximidade que destrói a possibilidade de qualquer "atividade política real", elas nos expõem radicalmente a esses mesmos poderes. No limite, exigem que os confrontemos ao preço de assumir de forma sacrificial (nos ritos sancionados do heideggerianismo) o risco da morte que advém, não da paralisia e do pânico irracional, mas de uma faticidade que está longe de ser "uma causalidade abstratamente separada e erigida indevidamente

e consequente de destituir tais relações -- por isso, uma teoria da potência destituinte, como marca da última fase do homo sacer (AGAMBEN, 2014, p. 295-310) -- e a procura por uma saída ética que oscila, e tenta produzir um "nada de representação" em que se dão uma filosofia do contato (Colli) e do aberto (Heidegger). Ela indicaria, para além do ser e da política, que destitui e torna inoperosos, um êthos ( $\tilde{\eta} \theta 0 \varsigma$ ) que é, já, um habitar e um hábito que, em curto-circuito, designam a potência da forma-di-vita. Por isso, o último limiar de Altissima povertà pode findar com a pergunta: "Qual ontologia e qual ética corresponderão a uma vida que, no uso, se constitui como inseparável da sua forma?” (AGAMBEN, 2014, p. 147). 
em soberano", porque se apresenta já, de fato, como "uma possibilidade repentinamente real" (AGAMBEN, 2020g) ${ }^{5}$.

Proponho retomar as preocupações ético-políticas de Agamben com o fim da proximidade e a virtual impossibilidade de "qualquer atividade política real", para ressignificá-las em uma chave de leitura materialista e pós-estrutural. Suas preocupações sugerem que nos perguntemos "o que se pode esperar do futuro das lutas?"; "o que será da política na era do distanciamento social?", mas deixam de formular a pergunta que consiste em saber se "existe apenas um tipo de 'atividade política real' -- aquela que exige o contato factício entre os corpos?". Esses parecem ser alguns dos problemas que poderiam ser pensados com Agamben e para além das condicionantes que dão forma a seu pensamento.

$\mathrm{Na}$ contramão do que uma imaginação política demasiado atenta aos poderes poderia supor, minha hipótese é de que o campo social pós-pandêmico constitui um solo fértil ao florescimento de novas lutas, estratégias, e relações de composição política entres os corpos. Ousaria dizer que está em curso uma conspiração dos vivos para os quais a asfixia constitui um terreno material e urgente de luta. Essa afirmativa está longe de ser um wishful thinking, a exemplo da revolução viral de Slavoj Žižek (2020), mas está apoiada em uma série de experiências em curso.

Essa hipótese se apoia na hibridação de três premissas. A primeira é retirada à esquizoanálise que se vê lentamente cumular de uma análise micropolítica e segmentar, e que será proposta por Deleuze e Guattari entre O Anti-Édipo ([1972] 2010) e Mil Platôs ([1980] 2007). Nela, o campo social é definido não como uma infraestrutura, ou sob a forma de um conjunto de constantes estruturais variáveis, mas como um tecido de agenciamentos concretos entre elementos heterogêneos em variação contínua definido mais por linhas de invenção social do que de limitação ou parada. Deleuze e Guattari não cessaram de afirmar: "pode-se partir [...] da linha de fuga: talvez seja ela a primeira" (2007, p. 79); ou então, "diz-se erroneamente [...] que uma sociedade se define por suas contradições. [...] uma sociedade se define por suas linhas de fuga” (DELEUZE; GUATTARI, 2007, p. 94). O fato é que:

uma sociedade, um campo social não se contradiz; mas ele foge, e isso é primeiro; ele foge de antemão para toda parte; [...]. Longe de estar fora do campo social ou de sair dele, as linhas de fuga constituem o seu rizoma ou a sua cartografia. As linhas de fuga [...] são as pontas de desterritorialização nos agenciamentos de desejo (DELEUZE, 2016, p. 132).

A segunda premissa coincide com a afirmação da realidade dos processos que ocorrem nas redes e nos ambientes digitais e cibernéticos. Ela poderia ser invocada em uma grande diversidade de autores que se dedicam a analisar o capitalismo cognitivo, o capitalismo imaterial,

\footnotetext{
${ }^{5}$ Nesse sentido, L'invenzione di una epidemia, texto de 26 de fevereiro de 2020, deve ser interpretado como o que Heidegger chamaria de um "erro sobre o hoje", ao envolver e orientar a faticidade em uma névoa hermenêutica. O texto de Agamben faz expressa referência a Giovanni Maga (2020), um virologista italiano que afirmou em uma nota publicada no site do Consiglio Nazionale delle Ricerche (CNR) que o Coronavírus assemelhava-se a uma influenza comum e representava um baixo risco de mortalidade, concentrado em populações idosas e pacientes com comorbidades. Isso dá a Agamben o solo fático para lançar o argumento polêmico, e de tom conspiratório, de que a epidemia seria uma invenção que apropriaria o lugar até então ocupado pelo terrorismo e pelos controles globais antiterror nas estratégias dos podes constituídos. Duas semanas depois, o CNR retirou a nota de Maga da timeline de informações sobre o coronavírus, mas Agamben prosseguiu por mais de uma dezena de textos com seu argumento confinado a um plano ético-político, reivindicando filosoficamente o seu divórcio em relação à faticidade e à operatividade. E isso se exprime duplamente: na desvalorização da vida nua como vida fática, e na depreciação do risco pandêmico segundo a mesma via que vai revelar, mais tarde, a subsunção do plano ético-político ao registro hermenêutico.
} 
o biocapitalismo ou o semiocapitalismo. Para encurtar caminho, Matteo Pasquinelli (2008, p. 47) suscitou em Animal Spirits a materialidade das infraestruturas comuns que o capital "imaterial parasita", e não nos deixou esquecer que sua aparente evanescência é função do diagrama técnico, misto de material e imaterial, que conecta o semiótico (a digital life) à esfera biológica dos corpos (an everyday life), que procede à extração energética do trabalho vivo (PASQUINELLI, 2008, p. 65).

De outro ponto de vista, Stefanno Quintarelli (2019) recusará a correspondência intuitiva entre o real e o material, e o virtual e o imaterial, afirmando a realidade do imaterial. Ou, ainda, em uma chave radicalmente crítica aos teóricos do capitalismo cognitivo, Tiqqun (2020, p. 91) recusava que a tecnologia e a ciência fossem meras ideologias sobrepostas ao tecido concreto das relações intersubjetivas, mas, sim, "ideologias materiais", "[...] dispositivos em cascata, governamentalidade concreta que permeia aquelas relações".

A terceira premissa consiste em uma crítica que Judith Butler endereçou à concepção arendtiana do político, a qual Agamben parece ambiguamente repercutir. Segundo Arendt, o político designaria a esfera pública integrada por vidas de antemão liberadas das necessidades da vida reprodutiva.

A fim de formular sua política performativa dos corpos, baseada na distribuição diferencial da condição precária no capitalismo (BUTLER, 2018, p. 41 e p. 157) -- com a qual não precisamos estar inteiramente de acordo --, Butler esgrima a desconexão arendtiana entre os corpos e a possibilidade do exercício político da liberdade: "já estamos no político quando pensamos sobre transitoriedade e mortalidade", quando abordamos a questão "do ponto de vista da distribuição demográfica desigual de precariedade" (BUTLER, 2018, p. 55).

Por um lado, isso se explica pelo fato de que, para Butler (2018, p. 216), são biopolíticos "os poderes que organizam as vidas, incluindo aqueles que expõem diferencialmente as vidas à condição precária [...]”. Assim, interrogar a vida de um ponto de vista ético-político significa negociar imediatamente com essas formas de poder e com a precariedade cuja distribuição desigual eles organizam.

Por outro lado, a vulnerabilidade das vidas não é um fator ontológico, puramente fático ou constitutivo do vivo. A ontologia dos corpos é uma política, de modo que eles não podem ser abstraídos (mesmo sob a forma da pura faticidade) das relações de poder que os constituem (BUTLER, 2018, p. 162). É a sua precariedade, ativamente construída, organizada, desigualmente distribuída, formando vulnerabilidades capazes de estabelecer alianças transversais, que pode constituir uma valência política específica (BUTLER, 2018, p. 157).

Esse argumento de Butler, sobre a vulnerabilidade, a precariedade e, no limite, a descartabilidade das vidas, talvez seja ainda eufêmico demais para qualificar os tempos que correm. Achille Mbembe (2018, p. 10-11), filósofo camaronês radicado na África do Sul, chamará necropolíticas às "formas de soberania cujo projeto central [...] [é] 'a instrumentalização generalizada da existência humana e a destruição material de corpos humanos e populações"” que "constituem o nomos do espaço político em que vivemos". Por sua vez, Alliez e Lazzarato (2015) preferem falar em guerras fractais, ou em guerras contra populações (mulheres, homossexuais, negros, muçulmanos, pobres etc.) como expressão endocolonial da máquina de guerra do capital.

Essas três premissas são centrais para escapar ao determinismo com que Agamben liga a crise de proximidade, o distanciamento social e a impossibilidade de toda atividade política "real". A abstrata faticidade do vírus, ou a tonalidade emocional do medo, confinam, mas não determinam uma completa asfixia das lutas; em boa medida, parecem denotar que a asfixia é um terreno de luta em que está em jogo a nossa "vida de ser vivo" (FOUCAULT, 2009, p. 156). 
E esta "vida de ser vivo" é a contração de todas as antinomias que configuram os agenciamentos de poder entre o biocapitalismo, difundido em escala global, e os corpos, que, mais ou menos integrados aos circuitos extrativos e de exploração do capital, constituem sua sede material; funcionam como pontes e nós psicobiofísicos na logística e nos circuitos de circulação e valorização que tomam o vivo como um "terminal biopolítico". Além disso, a diversidade estratégica, tática e sociotécnica de tais circuitos parece expandir o terreno do que Agamben parece compreender por "atividade política real".

\section{O futuro das lutas?}

O futuro das lutas é um problema mal colocado, porque ele eclipsa a pregnância de um conjunto mais vasto e difuso de ações em curso. Todo futuro das insurgências se encontra depositado menos no vírus, nas injunções do distanciamento social, no desmoronamento da proximidade, do que na atualidade das lutas que, talvez sob formas infinitamente contraídas, se desenvolvem em um terreno comum designado pela pandemia, mas não confinado a ela.

A pandemia é muito menos um fato bruto e pontual, de cuja faticidade Agamben pretende escapar, do que um processo de variação e de contínua recomposição de poderes, corpos, subjetividades e possíveis que misturam as escalas global e infinitesimal da vida dos vivos. Ao mesmo tempo em que tudo parece impedir a proximidade e, com isso, dificultar as dinâmicas mais clássicas de aliança política, fundadas na corporeidade e no estar-junto, ela não origina laboratórios de experimentação dos poderes e da contrainsurgência sem dispensar inadvertidamente balões de ensaio de antagonismos potenciais no campo social.

Por isso, se estivermos preocupados com o futuro das lutas, olharemos na direção das formas infinitesimais e contraídas que a sua atualidade manifesta sob a forma da reemergência inesperada, da renovação de estratégias e das novas composições políticas entre os corpos, que podem fazer da distância um elemento tático para proliferações estratégicas; e da corporalidade, a assunção absurda de uma posição impossível, uma prova atlética, um "querer-viver obstinado, cabeçudo, indomável, diferente de qualquer vida orgânica” (DELEUZE, 1997, p. 151). Ou, como Pasolini (2015, p. 179): “[...]não tomei o optalidon, me treme a voz / de garoto enfermo ] - / Eu? Uma vitalidade desesperada”.

$O$ vírus lança o terreno comum das lutas dessa disperata vitalità, que tanto pode ser enunciado na forma axiomática de um direito à respiração universal (MBEMBE, 2000), como ao modo desterritorializado que o prepara: a ameaça ecumênica da asfixia. Nesse terreno, o vírus nos encontra a todos, segundo as articulações e divisões segmentares que se desdobram em distribuições desiguais da exposição ao risco (BUTLER, 2020).

O risco da asfixia assume a forma híbrida e global de uma necropolítica e de uma guerra às populações que se encarrega de produzir, reproduzir e tornar eficazes "as divisões de classe, sexo, raça e subjetividade da população" (ALLIEZ; LAZZARATO, 2015, p. 334). O vírus percorre e contamina de maneira cruelmente díspar essas divisões, que são produzidas no cruzamento entre o global e o hiperlocal, no foco em que os corpos são penetrados, arrastados, agenciados e constituídos, divididos, polarizados, segregados ou deixados livres para fluir em direção à própria morte pelas finanças, que formam com eles uma só semiótica mista.

É precisamente neste terreno que o vírus encontra George Floyd, o ex-segurança negro de 46 anos asfixiado por policiais brancos de Minneapolis, cujo assassinato provoca a reemergência do black lives matter em aliança transversal com os antifascistas, e se difunde globalmente em 
revoltas pandêmicas (CORRÊA, 2020). Em poucos dias, I can't breathe se transformava no ritornelo, no enunciado coletivo em terceira pessoa, que tornava repentinamente visível a asfixia universal como um risco efetivo em toda a sua polimorfia, ao mesmo tempo em que o constituía como um terreno de luta. Eis o ponto irrepresentável em que o direito universal à respiração, no nível dos axiomas, e as lutas contra a asfixia, na hibridação entre o global e o hiperlocal, o material e o imaterial, testemunham o monismo das lutas, e definem a epidemia como seu centro ao mesmo tempo ambíguo, arriscado, múltiplo e comum.

Esse terreno é sempre determinado. Para muito além das políticas de lockdown, e contra os negacionismos de Estado ${ }^{6}$, as casas se tornam espaços ecopolíticos globais (COCCIA, 2020), meios em que a vida se desenrola, zonas autônomas em que os vivos, ainda que não saibam, conspiram. As casas não são o revés da pólis; são a pólis fragmentada e dispersa em enclaves da luta contra a asfixia viral, e também contra o negacionismo eugenista dos governos. Como não perceber que, se o lockdown pode ser um instrumento de desmobilização e de poder, o \#stayathome não se resume a um dispositivo, mas encarna, paradoxalmente, um movimento autônomo que faz da distância social uma ferramenta tática da luta contra a asfixia universal?

Parte do trabalho, do consumo e da vida social serão recaptados pelas Big Techs e pelas plataformas do capitalismo cibernético, e o home office parece se tornar a regra entre trabalhadores não-precários. Isso gera uma pressão e uma acumulação entre atividades produtivas e reprodutivas sem precedentes, que incidirão especialmente sobre o trabalho tradicionalmente feminino reprodutivo, não remunerado e não-comercializado. Aumentam os casos de violência doméstica (UNFPA, 2020), como mais uma expressão do cruzamento entre a dimensão pandêmica global e a ativação dos microfascismos e micropoderes hiperlocais, e suas divisões. No entanto, mesmo esse processo não tem sentido único, e possui ambiguidades que podem ser politicamente exploradas.

$\mathrm{Na}$ medida em que a casa passa a concentrar espacial e temporalmente todos os trabalhos, a centralidade da reprodução, especialmente da não-comercializada (FEDERICI, 2020 e 2019, p. 324-353), se torna visível e palpável de modo inédito. A vida política é corporalmente afetada pela vida doméstica, e se mistura fricativamente com ela. Isso abre báscula para um novo regime de percepções coletivas que podem estar na origem de uma tradução entre lutas e de seu próprio futuro: "Precisamos de uma luta muito ampla", diz Federici (2020).

O tornar-se doméstico de muitos dos trabalhos permite preparar desde logo o seu devir-mulher. No capitalismo global, os circuitos de circulação açambarcam maquinicamente a produção. Desse modo, todo trabalho, mesmo o "tradicionalmente produtivo", que caracterizou o trabalho masculino e fabril em torno do qual se organizavam as lutas operárias no século XIX, subsume-se agora às mesmas condições do trabalho usualmente doméstico, feminino, reprodutivo e não-remunerado.

Isso implica uma abertura transversal e anticapitalista dos feminismos que, antecipando o "devir-mulher do trabalho e do mundo", agenciam-se com as lutas em curso pela implementação de políticas de renda básica universal, que nada mais são do que remunerações por trabalhos reprodutivos, afetivos, não-comercializados, vinculados ao cuidado, tradicionalmente realizados por mulheres, segundo o binarismo da divisão sexual do trabalho.

A reivindicação em favor da renda básica ganhou impulso na situação pandêmica, e atingiu um patamar global de preocupação (WIGNARAJA, 2020). Todavia, as soluções apresentadas

${ }^{6}$ Como os negacionismos também polimorfos de Donald Trump, dos Estados Unidos, Jair Bolsonaro, do Brasil, Alexander Lukasheko, da Bielorrússia, Gurbanguly Berdimuhamedow, do Turcomenistão, e Daniel Ortega, da Nicarágua. Cf., a respeito, a reportagem de Alves e Grohmann (2020). 
permanecem paradoxalmente locais e atreladas às estruturas orçamentárias e de endividamento dos Estados-Nação. Isso manifesta uma clara assimetria entre a subsunção planetária dos processos de valorização biopolíticos pelo capital global e a obsolescência das soluções meramente westfalianas.

Ainda que experimentemos hoje uma escalada sem precedentes da plataformização em geral da vida, é no interior ambíguo e incômodo desse fenômeno que algo como o \#BrequedosApps pode surgir como um desejo de fazer os corpos e a vida tomarem de assalto os operadores logísticos de servidão maquínica. Que estejamos no coração da hipótese cibernética (TIQUUN, 2020), segundo a qual o social coincide radicalmente com os dispositivos técnicos de poder, governamentalidade e circulação do capital, de tal forma que todo antagonismo parece antecipar a sua preste assimilação sistêmica: como não ver no \#BrequedosApps uma sabotagem infraestrutural e logística dos algoritmos promovida pelos corpos? As greves, horizontal e telematicamente organizadas, agidas no nível dos corpos com manifestações compostas por milhares de entregadores por todo Brasil, provocam interferência e ruído (BURROUGHS, 2013) nos maquinismos binários e nas plataformas dos exploradores logísticos.

Assim como o caso George Floyd produz uma conexão transversal entre a questão negra, a violência policial, o racismo de Estado e os movimentos autônomos e antifascistas, o \#BrequedosApps contesta o sequestro da autonomia do trabalho por meio de uma conexão transversal entre os cachorros-lokos metropolitanos, a horizontalidade dos entregadores antifascistas ${ }^{7}$, e o comando consumerista e co-produtor (DUJARIER, 2014) (playboy ou não) do \#stayathome.

Em um só lance de dados, o \#BrequedosApps contesta: 1/ a saturação do desejo pela plataforma: a fome (do entregador e do consumidor) subsumida ao axioma algorítimico; 2/ a gameficação da exploração logística cotidiana: a dimensão real do App, que mobiliza a vulnerabilidade logística dos corpos, e seu estatuto de jogo desprovido de consequências, co-produzido pelos consumidores; 3/ o neofeudalismo de plataforma: o operador logístico que já não açambarca só uma taxa sobre as entregas, mas distribui como um senhor neofeudal a própria chance de produzir, e o faz desigualmente, com base em dataísmos, avaliações próprias e critérios secretos (os arcana imperii algorítmicos); 4/ o regime de servidão maquínica: os corpos biológicos, expostos a todos os riscos, incluída a contaminação por Covid-19, como infraestrutura psicobiofísica dos exploradores logísticos; e 5/ o regime de sujeição social, que define os trabalhadores dos Apps como precários desprovidos de direitos e garantias mínimas (o que corresponde à luta na dimensão dos axiomas).

Eis, então, três exemplos velozes sobre como o futuro das lutas está contido, sob uma forma infinitesimal e contraída, nas lutas do presente. Três formas de conspiração dos vivos que tomam a pandemia como um terreno imanente de lutas. Primeiro, as lutas que se travam no devir-ecopolítico das casas. Segundo, as transversalidades e afinidades eletivas que se cruzam nas lutas antirracistas e antifascistas, nas lutas feministas e pela renda, em fricção paradoxal com os circuitos de circulação e reprodução da vida global. Terceiro, nas lutas propriamente cibernéticas, que podem descerrar um liame de solidariedade no ponto de clivagem e de divisão operado pelas plataformas de exploração logística. É a conversão de uma relação entre trabalhador-de-plataforma e consumidor-co-produtor sígnico, operada em regime de servidão maquínica e sujeição social (LAZZARATO, 2014), em um contato imanente que destitui tal relação na forma ético-política imanente de um contato.

${ }^{7}$ Cf., sobre isso, Alves e Grohmann (2020), que entrevistaram Paulo Lima, o Galo de Luta, dos entregadores antifascistas. 


\section{Considerações finais}

Se as sociedades se definem por suas linhas de fuga, Deleuze e Guattari alertaram incessantemente que, assim como as grandes divisões contraditórias, as linhas de fuga nunca bastam. Elas não contêm menos perigos do que chances, e por essa razão, devem ser operadas com prudência, ou arriscam se transformar em linhas de morte e de abolição completa, proliferando estratos cancerosos (DELEUZE; GUATTARI, 2008, p. 25-27).

Prova disso é que não existem apenas lutas contra a asfixia, mas a asfixia constitui um terreno de lutas, um plano de composição política distendido e povoado em escala global. Paradoxalmente, existem protestos cívicos assassinos (como os anti-mask protests americanos), políticas genocidas, os "deixar-morrer" capitalisticamente organizados, os "fazer-morrer" necropolíticos e racistas, que definem um outro estriamento deste mesmo terreno: um antimovimento global pró-asfixia. Manifestações que se reúnem em torno de uma suposta "resistência", cega e de rebanho, contra as respostas à pandemia. E trata-se de protestos espalhados pelos cinco continentes ${ }^{8}$, tão difusos e pervasivos quanto os microfascismos alt-right. Mais um sinal de que não cessamos de fugir, mas também temos fugido suicidariamente, transformando a linha de fuga em uma linha de abolição.

Ante o real, é impossível perguntar sobre o futuro das lutas. É impossível imaginar que a "atividade política real" esteja confinada aos corpos ou à esfera pública, em regime de lockdown ontológico-político, como Agamben parece pressupor. É absurdo negar o caráter político das lutas contra a asfixia que fazem do distanciamento uma das componentes táticas para fazer proliferar suas estratégias em redes que só existem como semióticas mistas; isto é, redes que se sustentam nos agenciamentos maquínicos entre elementos heterogêneos -- entre os quais, os corpos, as ruas, as casas, o desejo de viver, a revolta contra os racistas, contra os governos, contra os assassinos. Os signos são, já, imediatamente, um misto incindível de enunciado coletivo em terceira pessoa e corpo fabricado qualquer, como o ritornelo torturante de George Floyd; una disperata vitalità de Pasolini.

Como não poderiam haver alianças entre corpos que se mantêm à distância? Que vivem o distanciamento como uma forma conjuntural tão densa e proliferante quanto qualquer proximidade? É no interior dessa aliança, em que a distância e a prudência tornam-se ferramentas táticas, e integram um ethos efetivo, que as lutas se multiplicam globalmente. Trabalhadorxs domésticxs, black lives matter, antirracistas, antifascistas, entregadores, co-produtores, usuários de plataformas etc., seguem sendo nós de revoltas logísticas possíveis contra seus operadores maquínicos, contra a captura da riqueza da circulação biopolítica pelo capital, e tendem a estabelecer materialmente um novo sentido da circulação, do tempo, da vida, da sua reprodução, e da sua riqueza.

Fugimos por todos os lados, e em contato com todas as ambiguidades perigosas e pregnantes desse terreno. Não temos cessado de fugir monasticamente, reprodutivamente, transversalmente, ciberneticamente, suicidariamente. E toda fuga, por menor que seja, assombra como uma atividade política real demais em que celebramos núpcias e trocamos alianças transversais contra a maldição do impossível.

\footnotetext{
${ }^{8}$ Uma página wiki reuniu e disponibilizou uma série de notícias relacionadas a protestos pró-asfixia. Disponível em: <http:// pt.wikipedia.org/wiki/Protestos_contra_respostas_\%C3\%A0_pandemia_de_COVID-19\#cite_note-37>
} 


\section{Referências}

AGAMBEN, G. Sulla fine del mondo. Quodlibet. 19 de novembro de 2019. Disponível em: <https://www. quodlibet.it/giorgio-agamben-sulla-fine-del-mondo>. Acesso em: 13 jul. 2020.

AGAMBEN, G. L'invenzione di un'epidemia. Quodlibet. 26 de fevereiro de 2020a. Disponível em: <https://www.quodlibet.it/giorgio-agamben-l-invenzione-di-un-epidemia>. Acesso em: 13 jul. 2020.

AGAMBEN, G. Biosicurezza e politica. Quodlibet. 11 de maio de 2020b. Disponível em: <https://www. quodlibet.it/giorgio-agamben-biosicurezza>. Acesso em: 13 jul. 2020.

AGAMBEN, G. Distanziamento sociale. Quodlibet. 6 de abril de 2020c. Disponível em: <https://www. quodlibet.it/giorgio-agamben-distanziamento-sociale>. Acesso em: 13 jul. 2020.

AGAMBEN, G. La medicina come religione. Quodlibet. 2 de maio de 2020d. Disponível em: <https:// www.quodlibet.it/giorgio-agamben-la-medicina-come-religione>. Acesso em: 13 jul. 2020.

AGAMBEN, G. Una domanda. Quodlibet. 14 de abril de 2020e. Disponível em: <https://www.quodlibet. it/giorgio-agamben-una-domanda>. Acesso em: 13 jul. 2020.

AGAMBEN, G. Fase 2. Quodlibet. 20 de abril de 2020f. Disponível em: <https://www.quodlibet.it/ giorgio-agamben-fase-2>. Acesso em: 13 jul. 2020.

AGAMBEN, G. Che cos'è la paura? Quodlibet. 13 de julho de 2020g. Disponível em: <https://www. quodlibet.it/giorgio-agamben-che-cos-u2019-a-paura>. Acesso em: 13 jul. 2020.

AGAMBEN, G. L'Aperto: l'uomo e l'animale. Torino: Bolatti Boringhieri, 2002.

AGAMBEN, G. Homo sacer I: o poder soberano e a vida nua. Belo Horizonte, 2007.

AGAMBEN, G. O uso dos corpos. Homo sacer IV, 2. São Paulo: Boitempo, 2017.

AGAMBEN, G. Altíssima pobreza. Regra monásticas e forma de vida. Homo sacer IV, 1. São Paulo: Boitempo, 2014.

ALLIEZ, E.; LAZZARATO, M. Guerres et capital. Paris: Éditions Amsterdam, 2016.

ALVES, P.; GROHMANN, R. É luta de classes mesmo, sem conversinha: entrevista com Galo, dos Entregadores Antifascistas. DigiLabour. 02 de julho de 2020. Disponível em: <https://digilabour.com. br/2020/07/02/e-luta-de-classes-mesmo-sem-conversinha-entrevista-com-galo-dos-entregadoresantifascistas/>. Acesso em: 13 jul. 2020.

BARBOSA, J.; HONESKO, V. N. Modos colonizados de repcepção filosófica: notas sobre o caso Agamben. Flanagens. 15 de maio de 2020. Disponível em: <http://flanagens.blogspot.com/2020/05/jonneferbarbosa-1-vinicius-nicastro.html>. Acesso em: 13 jul. 2020.

BOURROUGHS, W. S. La revolución electrónica. Buenos Aires: Caja Negra, 2013.

BUTLER, J. Corpos em aliança e a política das ruas. Notas para uma teoria performativa de assembleia. Rio de Janeiro: Civilização Brasileira, 2018.

BUTLER, J. Traços humanos nas superfícies do mundo. Coleção pandemia crítica. São Paulo: n-1 edições, 2002. Disponivel em: <https://n-1edicoes.org/042>. Acesso em: 13 jul. 2020.

CANETTI, E. Massa e poder. São Paulo: Companhia das Letras, 2019. 
COCCIA, E. Reversing the new global monasticism. 21 de abril de 2020. Fall semester. Disponível em: <https://fallsemester.org/2020-1/2020/4/17/emanuele-coccia-escaping-the-global-monasticism> Acesso em: 13 jul. 2020.

COLLI, G. La ragione errabonda. Quaderni Postumi. Milano: Adeplhi Edizioni, 1982.

CORRÊA, M. D. C. Entre o transe e a asfixia: a conspiração do vivo. Coleção pandemia crítica. São Paulo: n-1 edições, 2020. Disponivel em: <https://n-1edicoes.org/076>. Acesso em: 13 jul. 2020.

CORRÊA, M.; MATOS, A. Viral intrusion. Naked punch. 31 de maço de 2020. Disponível em: <http:// www.nakedpunch.com/articles/308>. Acesso em: 13 jul. 2020.

DELEUZE, G.; GUATTARI, F. O anti-Édipo. São Paulo: Editora 34, 2010.

DELEUZE, G.; GUATTARI, F. Mil Platôs: capitalismo e esquizofrenia, vol. 3. São Paulo: Editora 34, 2008.

DELEUZE, G.; GUATTARI, F. Crítica e clínica. São Paulo: Editora 34, 1997.

DUJARIER, M.-A. Le travail du consommateur. De McDo à eBay, comment nous coproduisons ce que nous achetons, Paris, La Découverte, 2014.

DWIVEDI, D; MOHAN, S. A comunidade dos abandonados: uma resposta para Agamben e Nancy. 08 de março de 2020. Coleção pandemia crítica. São Paulo: n-1 edições. Disponível em: <https://n-1edicoes. org/085>. Acesso em: 13 jul. 2020.

ESPOSITO, R. Curati a oltranza. 28 de fevereiro de 2020. Antinomie. Disponível em: <https://antinomie. it/index.php/2020/02/28/curati-a-oltranza/>. Acesso em: 13 jul. 2020.

FEDERICI, S. O ponto zero da revolução. Trabalho doméstico, reprodução e luta feminista. São Paulo: Elefante, 2019.

FEDERICI, S. Capitalismo, reprodução e quarentena. Coleção pandemia crítica. São Paulo: n-1 edições, 2020. Disponivel em: <https://n-1edicoes.org/058>. Acesso em: 13 jul. 2020.

GRILLO, A. Agamben e a pergunta equivocada. IHU Online, 2020. Disponível em: <http://www.ihu. unisinos.br/78-noticias/598179-agamben-e-a-pergunta-equivocada-artigo-de-andrea-grillo>. Acesso em: 13 jul. 2020.

FOUCAULT, M. História da sexualidade 1: a vontade de saber. 19. ed. Rio de Janeiro: Graal, 2009.

FRATESCHI, Y. Agamben sendo Agamben: o filósofo e a invenção da pandemia. Blog da Boitempo, 2020a. Disponível em: <https://blogdaboitempo.com.br/2020/05/12/agamben-sendo-agamben-ofilosofo-e-a-invencao-da-pandemia/>. Acesso em: 13 jul. 2020.

FRATESCHI, Y. Essencialismos filosóficos e ditadura do corona: sobre Giorgio Agamben mais uma vez. Blog da Boitempo, 2020b. Disponível em: <https://blogdaboitempo.com.br/2020/05/29/ essencialismos-filosoficos-e-ditadura-do-corona-sobre-giorgio-agamben-mais-uma-vez/>. Acesso em: 13 jul. 2020.

LAZZARATO, M. Signos, máquinas, subjetividades. São Paulo n-1 edições, 2014.

LUCAS, Á. A triste sorte dos negacionistas da Covid-19. Jornal El país. 07 de julho de 2020. Disponível em: <http://brasil.elpais.com/internacional/2020-07-07/a-triste-sorte-dos-negacionistas-da-covid-19. html>. Acesso em: 13 jul. 2020.

HEIDDEGER, M. Ser e tempo. 4. ed. Petrópolis: Vozes, 2009. 
HEIDDEGER, M. Ontologia (hermenêutica da faticidade). Petrópolis: Vozes, 2012.

MAGA, G. Rischio basso, capire condizioni vittime. CNR - Consiglio Nazionale delle Ricerche. 22 de fevereiro de 2020. Disponível em: <https://www.cnr.it/it/nota-stampa/n-9233/coronavirus-rischiobasso-capire-condizioni-vittime>. Acesso em: 13 jul. 2020.

MBEMBE, A. Necropolítica. Biopoder, soberania, estado de exceção, política da morte. São Paulo: n-1 edições, 2018.

MBEMBE, A. O direito universal à respiração. Coleção pandemia crítica. São Paulo: $n-1$ edições. Disponivel em: <https://n-1edicoes.org/020>. Acesso em: 13 jul. 2020.

MORAES, J. de. Agamben contra o neoliberalismo. Tempo de agora, 2020. Disponível em: <https:// www.tempodoagora.org/post/agamben-contra-o-neoliberalismo>. Acesso em: 13 jul. 2020.

NANCY, J.-L.. Eccezione virale. 27 de fevereiro de 2020. Antinomie. Disponível em: <https://antinomie. it/index.php/2020/02/27/eccezione-virale/>. Acesso em: 13 jul. 2020.

PASOLINI, P. P. Poemas. São Paulo: Cosac Naify, 2015.

PASQUINELLI, M. Animal spirits: a bestiary of the commons. Rotterdam: NAi publishers, 2008.

PROTESTOS CONTRA RESPOSTAS À PANDEMIA DE COVID-19. Wikipedia: a enciclopédia livre. 2020. Disponível em: <http://pt.wikipedia.org/wiki/Protestos_contra_respostas_\%C3\%A0_pandemia_de_ COVID-19\#cite_note-37> Acesso em: 13 jul. 2020.

QUINTARELLI, S. Capitalismo immateriale. Le technologie digitale e il nuovo conflitto sociale. Torino: Bolatti Boringhieri, 2019.

RODRIGUES, C. et al. Agamben sendo Agamben: por que não? Blog da Boitempo, 2020a. Disponível em:<https://blogdaboitempo.com.br/2020/05/16/agamben-sendo-agamben-por-que-nao/>. Acesso em: 13 jul. 2020.

TIQQUN. The cybernetic hypothesis. South Pasadena: Semiotext(e), 2020.

UNFPA. Impact of the COVID-19 Pandemic on Family Planning and Ending Gender-based Violence, Female Genital Mutilation and Child Marriage (Report). United Nations Population Fund. Interim technical note. Disponível em: <https://www.unfpa.org/sites/default/files/resource-pdf/COVID-19_ impact_brief_for_UNFPA_24_April_2020_1.pdf>.Acesso em: 13 jul. 2020.

WIGNARAJA, K. The need for universal basic income. United Nations Development Program. Publicado em 06 de maio de 2020. Disponível em: <https://www.undp.org/content/undp/en/home/ blog/2020/the-need-for-universal-basic-income.html>. Acesso em: 13 jul. 2020.

ŽIŽEK, S. Pandemia: Covid-19 e a reinvenção do comunismo. São Paulo: Boitempo, 2020. 